\title{
Electricity End-Use Efficiency in Ghana: Experience with Technologies, Policies and Institutions
}

\author{
John Bosco Dramani \\ PhD Candidate, College of Law and Management, School of Accounting, Economics and Finance \\ University of KwaZulu-Natal (UKZN), South Africa; \\ e-mail:boscodramani@yahoo.co.uk
}

D.D. Tewari

Professor, College of Law and Management, School of Accounting, Economics and Finance University of KwaZulu-Natal (UKZN), South Africa e-mail:Tewari@ukzn.ac.za

Doi:10.5901/mjss.2013.v4n13p669

\begin{abstract}
For almost a decade, Ghana has experienced the application of technologies and policies intended to improve electricity enduse efficiency. The technologies included appliances, lighting, variable speed drivers and power factor correction while the policies comprised appliances standards and labels, mass adoption of electricity-saving lamps, financial and fiscal policies. A number of market failures hindered the penetration of these technologies and the study reviewed the extent to which these limitations prevented the success of these technologies. The role of institutions in influencing policy, prices, consumers and manufacturers or importers to improve the penetration of these technologies was regarded as important.
\end{abstract}

Keywords: Electricity, efficiency, appliances, policy, institutions

\section{Introduction}

For the last three decades (1970 to 2012), electricity generation in Ghana has more than quadrupled (World Bank, 2012; Energy Commission, 2013). However, total electricity generated per capita ${ }^{1}$ has been relatively low as it falls below that of the Organisation for Economic Co-operation and Development (OECD) countries by about 13 times, and 9 times lower than in the countries with transition economies (CET) (Levine, et al., 1995; World Bank, 2012). However, Gross Domestic Product (GDP) has merely doubled, implying a huge percentage of electricity generated has not been channelled into productive ventures, but rather has been wasted (Agyarko, 2010). Again, the governments of developing economies spend about 20 percent of their capital investment on the generation of electricity (Levine et al., 1995), but these countries continuously suffer from blackout and load shedding and environmental pollution attributed to electricity generation has been rising lately. This implies governments and other providers cannot meet the supply requirements of the electricity sector.

These increasingly negative issues in relation to the electricity generation capability of the country, has resulted in the need for a greater dependence on better-quality electricity end-use efficiency technologies to reduce the supply requirements. This study provides a review of the literature on electricity end-use efficiency in Ghana with respect to the following: (1) theory and evolution of electricity end-use; (2) types of technologies; (3) factors that hinder the utilization and extensive deployment of these technologies; (4) policies implemented to promote the increased deployment and use of these technologies; and (5) market transformation through institutions.

The rest of the study is organized as follows. Section two presents the trends in electricity generation and consumption. The evolution of electricity end-use efficiency policies is discussed in section three. The technologies that increase electricity end-use efficiency are presented in section four. Factors that hinder the utilization and extensive deployment of these technologies are presented in section five. The role of institutions in promoting electricity efficiency is summarized in section six, while section seven presents the conclusions.

\footnotetext{
1 The per capita electricity generated in 2012 is $464.2 \mathrm{kWh}$.
} 


\section{Trends in Electricity Generation and Consumption}

Since 1971, electricity generation has grown from 2944 GWh to 12024 GWh in 2012, representing about a 300 percent increase in generation (World Bank, 2012; Energy Commission, 2013). Figure 1 indicates a growth trend in generation with significant falls in 1983, 1997, 2003, 2007 and 2010, when the country experienced generation crises. These crises were broadly attributed to the following: (1) insufficient investment in new infrastructure (Adom et al., 2012: 530); (2) the failure of hydropower plants to supply adequate power due to perennial drought; (3) spontaneous outages at the Vridi thermal plant in Cote d'Ivoire where Ghana imported an average amount of $674.8 \mathrm{GWh}$ of electricity from 2000 to 2010 (Energy Commission, 2010); and (4) disruptions in natural gas supply, which affected thermal plant generation capability (Volta River Authority, 2012). Despite these crises, electricity generation on average grew by about 5.4 percent per annum from 1972 to 2012. Figure 2 shows the year-on-year percentage growth in electricity generation.

On the consumption side, electricity usage grew from 2764 GWh in 1971 to 9258 GWh in 2012, representing about a 234 percent increase. Figure 1 also shows an increasing trend in consumption with falls corresponding with the various years of crises as indicated earlier. However, the average percentage growth of consumption spanning 1972 to 2012 was 5.6 as compared to 5.4 percent of generation. This indicates a deficit situation of 0.2 percent per annum. Figure 2 shows the year-on-year percentage in electricity generation (gen), consumption (cons) and GDP per capita (GDPC). GDPC as indicated in Figure 2 is relatively positively correlated with electricity generation and consumption particularly between 1972 and 1984 .

The increasing electricity consumption, on the other hand, may be attributed to the following: (1) robust economic growth, as Ghana's GDP grew at an average of 7.9 percent between 2000 and 2012 (GRIDCo, 2010; Ministry of Finance, 2012); (2) rapid urbanization, as the country's urban population grew from 44 percent to 52 percent of the total population between 2000 and 2010 (GRIDCo, 2010); (3) the national electricity scheme (NES), which increased the number of communities connected to the grid from 49 percent in 2000 to 72 percent in 2012 (Energy Commission, 2012); and (4) an increase in the customer population to about 2.6 million (Energy Commission, 2012:12). In 2009, the total customer population accounted for a peak electricity demand of 1,423 MW and this estimate rose to 1,700 MW in 2011 representing about a 19 percent growth in peak demand (GRIDCo, 2010:11; Energy Commission, 2012). This leads to the conclusion that growth in electricity consumption needs to be tackled by increasing electricity efficiency (Levine, et al., 1995).

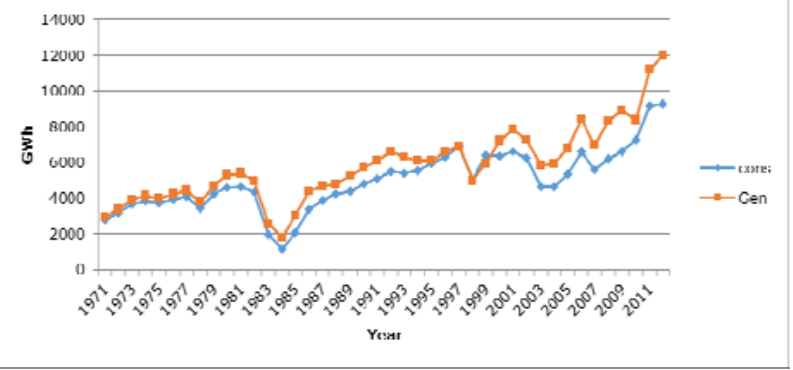

Figure 1: Trends in electricity generation and consumption

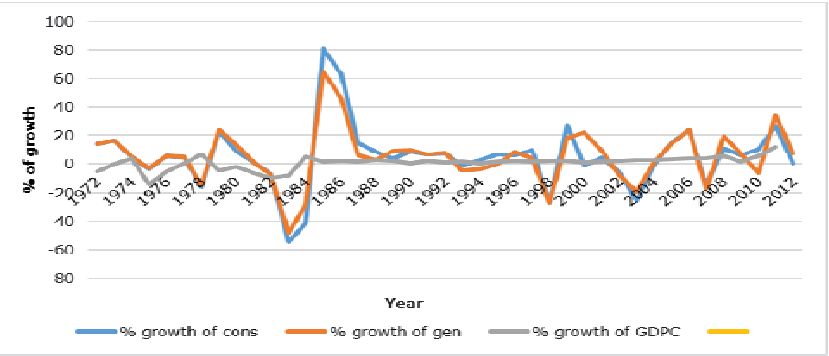

Figure 2: Percentage growth in electricity consumption, generation and real GDP per capita 


\section{Theory and Evolution of Electricity End-Use Efficiency Policies in Ghana}

This section presents the theory and evolution of electricity end-use efficiency.

\subsection{Theory of electricity end-use efficiency}

Electricity efficiency focuses on efficient technology and operational methods that offer a high amount of electricity service with less electricity utilization (Carley, 2012). According to Anderson (1993), the rationale for the quest for electricity efficiency can be categorized into four areas, namely: saving money ${ }^{2}$, reducing electricity dependence, combating the greenhouse effect and moving towards an electricity sustainable economy

Economic theory indicates that electricity efficiency preferences entail investment decisions that substitute larger initial capital costs and uncertainty for lesser future electricity usage costs (Gillingham et al., 2009). The initial cost is defined as the difference between the acquisition and installation costs of the efficiency strategy and the costs of the alternative that provides the consumer with the same service but is inefficient.

Undertaking investing in the electricity efficiency strategies involves an evaluation of the initial capital costs with the anticipated future savings. Evaluation of the future electricity savings in turn, requires an assessment of anticipated future electricity tariffs, the degree of usage of the appliance, the lifespan of the appliance and variations in other operating costs associated with electricity usage (Dubin \& McFadden, 1984). To compare the expected future flows of financial resources towards the initial costs of purchasing the appliances entails discounting future cash flows values to presents values. Assuming electricity consumption is constant, the user will optimize by selecting the level of electricity efficiency that minimizes the present value of costs. Thus, the consumer will undertake electricity efficiency strategies only when the perceived gains exceed the cost (Leonard \& Decker, 2012).

The theoretical perspective of electricity efficiency with respect to the household can be depicted by a production function framework, which defines capital and electricity as factors in the production process (Leonard \& Decker, 2012). Using an isoquant that defines a given level of electricity services, cost minimization of electricity usage is found at the point of tangency where the marginal rate of change in the capital cost brought by the change in electricity usage is the same as the ratio of the relative price (Leonard \& Decker, 2012). The relative price is determined by the cost of efficiency enhancements, the rate of discount, anticipated price of electricity, degree of appliance usage and the given time horizon. The lack of information on the electricity intensity of a particular efficiency strategy tends to reduce the relative prices of electricity resulting in the selection of an inefficient strategy.

Electricity markets and prices affect the amount of electricity usage and the decision to acquire improved electricity efficiency technology. A rise in electricity prices leads to minimal electricity saving in the short run because changes in electricity efficiency technologies are constrained by the long lifespan and sluggish yield of electricity appliances. However, in the long run a rise in electricity prices has the tendency to influence electricity efficiency significantly as consumers modify their appliance acquisition and firms introduce improved products and processes. Theoretically, the long-run price elasticities are usually bigger than in the short run; implying improved electricity demand efficiency is accomplished in the long run rather than in the short run (Gillingham et al., 2009).

Industrial and commercial consumers' willingness to participate in electricity efficiency issues can be analysed through the profit maximization framework. Based on this framework, these consumers will undertake electricity efficiency only if the profits are positive, indicating that the derived revenue exceeds costs.

\subsection{Evolution of electricity efficiency policies}

The formulation and implementation of electricity efficiency policies in Ghana started after the first oil shock in 1975 (Ofosu-Ahenkorah, 2002). To facilitate the process, the government of Ghana together with the utility providers established the National Energy Board (NEB) in 1985. Ofosu-Ahenkorah (2002) indicated the following as the role of the NEB, set up by legislation (PNDC Law 62): (1) to formulate policy on electricity for deliberation and endorsement by government; (2) to evaluate Ghana's electricity resources and scrutinize the functions of the utility providers as well as electricity utilization; and (3) to collect and develop a broad database and information on electricity resources for decision making.

2 Money saving is accomplished through the following: reduction in the proportion of consumer's income to electricity consumption, reduction in government subsidy to consumers and improvement in the financial capability of the electricity companies. 
Initially, the activities of the NEB were not taken seriously because of the relatively low electricity price, the lackadaisical attitude on the part of most consumers toward government programmes and the application of obsolete marketing methods (Edjekumhene, 2007). Promoting electricity efficiency, however, gained momentum in the 1990s when the Ministry of Energy took over the mandate after the demise of the NEB in 1991.

In 1997, the Energy Foundation (EF) was established to promote electricity efficiency. This foundation is a publicprivate sector initiative meant to promote efficiency by avoiding excessive bureaucracy, sluggishness and public mistrust, which hitherto characterized government institutions. To effectively implement efficiency policies it had to undertake two major activities, namely: (1) massification of awareness concerning electricity use and the ability to control its usage; and (2) eliminate completely the apathy of consumers towards electricity efficiency (Ofosu-Ahenkorah, 2007).

Again, in 1997, Ghana launched its first electricity efficiency exhibition with support from the United States Department of Energy. This further paved the way for closer collaboration between the Alliance to Save Energy and the Lawrence Berkeley National Laboratory (LBNL) to assist the Energy Foundation to devise minimum electricity performance standards for appliances. Later in the year, the Public Utility Regulatory Commission (PURC) Act (Act 538) and the Energy Commission (EC) Act (Act 541) were enacted and charged with tariff setting and the supply of licenses to the sector operators (Edjekumhene, 2001).

In 1999, LBNL in collaboration with the Energy Foundation undertook a survey entitled, Ghana residential energy use and appliance ownership survey: Formal report on the potential impact of appliance performance standards in Ghana (Constantine et al., 1999). This survey was meant to verify the prospective effects of electricity efficiency standards in Ghana. It thus became the basis upon which all electricity efficiency savings were undertaken. It also provided the minimum standard on domestic refrigerators, freezers, room air conditioners and lighting systems (Weil \& McMahon, 2005). Again the Energy Foundation organized a National Forum on Electricity Efficiency. This forum identified the barriers that hamper the implementation of mass electricity efficiency technologies and discussed solutions to these barriers (Energy Foundation, 2000).

In 2000, the first standards and labels were introduced into Ghana, which became known as the Collaborative Labelling and Appliance Standards Programme (CLASP) by the Alliance to Save Energy, LBNL and the International Institute for Energy Conservation. In 2001, room air conditioners with the minimum energy efficient ratio of 2.8 were introduced. The Ghana Standards Board also completed the label and examination techniques for room air conditioners in addition to refrigerators, lighting systems and deep freezes (Weil \& McMahon, 2005).

In 2002, a two-day workshop was organized by the Energy Foundation for members of parliament and other stakeholders to address the issues of importation and enforcement of electricity efficiency standards. The year 2003 marked the introduction of a labelling regime to make all importers and manufacturers affix labels bearing the minimum electricity efficiency standards on their products (Energy Commission, 2010). The years 2004 and 2005 witnessed the completion of testing facilities for the Ghana Standards Board to facilitate improved testing of imported goods and a 100 percent enforcement of standards to start in 2005 (Weil \& McMahon, 2005).

The year 2010 focused on the policy direction for electricity efficiency issues such as: (1) to promote the establishment of a Centre for Electricity Efficiency, and (2) to sustain the promotion of standards and labels (Ministry of Energy, 2010).

\section{The Technologies to Increase Electricity End-Use Efficiency}

The available technologies to increase electricity end-use efficiency in Ghana abound, particularly in the residential and industrial sectors. With respect to the residential sector, the potential to enhance electricity efficiency is significant in appliances, lighting and air conditioners. Turning to the industrial sector, electricity efficiency can be achieved by process changes. Process changes include electricity management, acquisition of efficient technologies over time and electricity saving in line with regulations and standards.

In analysing the efficient technologies, the study presents information and data on the cost effectiveness of each technology. According to Levine et al., (1995), technology effectiveness is evaluated using either the cost of electricity saved (CES) or the payback period. CES is defined as the levelized cost of saving electricity over the lifespan of an efficient technology. It is expressed in terms of costs per kWh.

\subsection{Residential electricity efficiency policies}

The objective of residential electricity efficiency policies are: (1) to reduce market barriers and stimulate the acceptance 
of electricity efficiency products and services, and (2) to protect consumers from unnecessarily high electricity bills due to inefficient appliances (Energy Commission, 2010). In Ghana, electricity efficiency policies can be categorized into two major groups known as mandatory efficiency policies and market-based efficiency policies (Energy Commission, 2010). Mandatory efficiency policies are obligatory measures or standards introduced by government agents to manage electricity usage. If suppliers refuse to abide by the required standards of efficiency policies delineated by the law they are made to face a legal or financial sanction or both. They are therefore considered to be the most efficient electricity policy-tools.

The market-based policies, on the other hand, involve the application of time-differentiated price signals and performance incentives for electricity consumption. The time-differentiated price-signals such as time-of-use pricing, realtime pricing and critical pricing are meant to reduce electricity consumption by promoting the acquisition of efficient appliances (Weil \& McMahon, 2005). Table 1 shows the categorization of electricity efficiency policies and the associated policy tools.

Table 1: Categorization of residential electricity efficiency policies in Ghana

\begin{tabular}{|c|c|l|}
\hline $\begin{array}{c}\text { Categorization of } \\
\text { policy }\end{array}$ & Policy tool & \multicolumn{1}{c|}{ Description } \\
\hline \multirow{4}{*}{ Mandatory } & Laws & $\begin{array}{l}\text { Government intends to reduce the end-use electrical wastage by implementing a } \\
\text { comprehensive demand-side management (DSM) Programme. }\end{array}$ \\
\cline { 2 - 3 } & $\begin{array}{c}\text { Comprehensive } \\
\text { policy }\end{array}$ & $\begin{array}{l}\text { Ghana's Strategic National Energy Plan, which sets a national target of } 10 \text { percent } \\
\text { renewable electricity generation in the country's energy mix by 2020. }\end{array}$ \\
\cline { 2 - 3 } & standards & Appliance standards and labeling for refrigerators and air conditioners. \\
\cline { 2 - 3 } & Lighting & $\begin{array}{l}\text { Legislative instrument to phase-out all incandescent bulbs and ensure least-cost } \\
\text { lighting in residential and non-residential buildings. }\end{array}$ \\
\hline \multirow{2}{*}{ Market-based } & Fiscal policy & $\begin{array}{l}\text { Reduction in import tax for manufactured and low electricity-usage appliances and } \\
\text { equipment. Direct and indirect subsidies to poor households to acquire electricity- } \\
\text { efficient appliances. }\end{array}$ \\
\cline { 2 - 3 } & Financial policies & $\begin{array}{l}\text { Soft loans to importers of air conditioners and refrigerators and to households to } \\
\text { purchase efficient appliances. } \\
\text { Refrigerator Rebate and Exchange Scheme: an innovative tool to transform the } \\
\text { refrigerating appliance market in Ghana by allowing consumers who turn in used } \\
\text { refrigerators financial support to pay part of the cost of new refrigerators. }\end{array}$ \\
\hline $\begin{array}{c}\text { Other information, } \\
\text { education and training }\end{array}$ & Social policies & $\begin{array}{l}\text { Educate the public on appliance standards and labels. } \\
\text { Educate consumers on how to read their meters weekly. }\end{array}$ \\
\hline
\end{tabular}

The policies and tools identified in Table 1 are succinctly discussed as follows:

Electricity laws: the laws regulating electricity that have a bearing on consumers' protection are the Public Utility Regulatory Commission (PURC) Act, 1997 (Act 538) and Energy Commission (EC) Act, 1997 (Act 541). DowuonaHammond \& Atuguba (2006) identified the functions of the PURC, which directly affect electricity efficiency, to include the following: (1) stipulating of procedures on tariffs; (2) evaluation and endorsement of tariffs; (3) investigating standards and quality; and (4) promoting fair competition among utility providers. The EC on the hand, undertakes the preparation, revision and updating of indicative national strategies to guarantee that all realistic electricity demands are met. It also puts in place a comprehensive database for decision making on the degree of development and utilization of electricity resources (Dowuona-Hammond \& Atuguba, 2006). The aim of the laws is to reduce waste in electricity usage attributed to the end-users.

Comprehensive electricity policy: it is embedded in the Strategic National Energy Plan (SNEP). Its objective is to make a contribution to the development of a robust electricity market that would offer adequate, viable and efficient electricity services for development of the economy by formulating a comprehensive strategy that recognizes the optimal path for development, utilization and efficient demand management (Energy Commission, 2006).

Appliances: household appliances such as air conditioners, refrigerators, television sets, electric cookers, etc. account for about 25 to 30 percent of electricity usage (Constantine et al., 1999). This is due to the large influx and utilization of second-hand appliances in the Ghanaian market. A United Nations report indicated that 85 percent of all electrical and electronic appliances imported are second-hand (United Nations, 2012). This implies that most household appliances are inefficient in drawing electricity. For example, in 1999, households in five regional capitals purchased and 
used 556 units of second-hand refrigerators as against 513 units of new refrigerators (Constantine et al., 1999). These second-hand refrigerators consume an average of 1200kWh of electricity per annum (Energy Commission, 2010). This indicates that there is great potential to save electricity through the application of new and efficient refrigerators. The new and efficient refrigerators, depending on the label, can save electricity ranging from $700 \mathrm{kWh} / \mathrm{year}$ to $950 \mathrm{kWh} / \mathrm{year}$, that is, on average about 20 percent of electricity can be saved. Table 2 shows the estimated electricity savings due to various types of refrigerators in Ghana.

Table 2: Estimated electricity saving for refrigerator labelling categories

\begin{tabular}{|c|c|c|c|c|}
\hline & Efficient type (new) & Inefficient type (used-ones) & $\begin{array}{c}\text { Electricity } \\
\text { savings }\end{array}$ & $\begin{array}{c}\text { Electricity cost } \\
\text { savings/annum }\end{array}$ \\
\hline Star Category & $\begin{array}{c}\text { New electricity consumption } \\
\text { (kwh/year) }\end{array}$ & $\begin{array}{c}\text { Average electricity existing } \\
\text { consumption (kwh/year) }\end{array}$ & Kwh/year & Ghs year. \\
\hline 5 star & 250 & 1200 & 950 & 162 \\
\hline 4 star & 300 & 1200 & 900 & 153 \\
\hline 3 star & 350 & 1200 & 850 & 145 \\
\hline 2 star & 400 & 1200 & 800 & 136 \\
\hline 1 star & 500 & 1200 & 700 & 119 \\
\hline $\begin{array}{l}\text { Estimated potential savings: Annual national electricity generation }=9,000 \mathrm{GWh}, \text { Estimated savings with established } \\
\text { standards and labels- 10\% of 9000 GWh = 900 GWh, Annual monetary savings = 900*10*0.17, (price of kilowatt hour of } \\
\text { electricity is } 0.17 \text { as charged by Electricity, Company of Ghana) = Ghs 153 million equivalent to US } \$ 102 \text { million }\end{array}$ \\
\hline
\end{tabular}

The estimated electricity saving of US\$102 million in Table 2 can only be realized with 100 percent utilization of new technology.

The estimated electricity saving brought by the application of efficient appliances was made possible through the adoption of policies on labels and Minimum Electricity Performance Standards (MEPS), which were passed into law in 2005 in the form of legal instruments LI 1815 and LI 1970.

Labelling provided electricity efficiency information affixed to appliances to indicate their performance level (Weil \& McMahon, 2005). This implied they are designed to resolve market failures ${ }^{3}$. Previously, electricity-drawing capabilities of many appliances were not known to consumers at the point of sale. As a result, many appliances that possessed higher electricity costs throughout their entire lifetime than their primary cost of purchase were unknown to consumers. The labels thus provided consumers with relevant data to undertake informed purchasing decisions. They also provided a benchmark for utilities and public agencies that gave consumers incentives to purchase efficient appliances (Weil \& McMahon, 2005). The labels ranged from 5-star (most efficient) electricity efficiency rating scale to 1-star (least efficient) (Energy Foundation, 2005).

The MEPS, on the other hand, are instruments of public policy that ban the sale and purchase of appliances that fail to comply with a specific amount of electricity usage (de Melo \& Jannuzzi, 2010). They were introduced to resolve information barriers and inadequacies, which led consumers to make illogical economic decisions. Even though more efficient appliances paid-off in the long run, consumers faced contending demands on their monetary resources and usually were unable to estimate future savings. MEPS were seen thus a mechanism to evade the huge transaction costs present in the market. Ghana's MEPS ban importers and manufacturers from retailing refrigerators that use more than $500 \mathrm{kwh} / \mathrm{year}$ of electricity and air conditioners with an electricity efficiency of below 2.8 watts (9.55BTU/Watt) of cooling per watt of electricity input (Energy Commission, 2010). The implementation of MEPS entailed undertaking steps such as technology evaluation, market appraisal and price-efficiency correlation, life-cycle costs of appliances and an estimation of prospective impacts (Constantine et al., 1999; de Melo \& Jannuzzi, 2010). Table 3 illustrates policies meant to stimulate the acquisition and utilization of efficient appliances.

Table 3: Policy stimulant in the acquisition of electricity-efficient appliances

\begin{tabular}{|c|l|c|}
\hline Policy instrument & \multicolumn{1}{|c|}{ Circumstances for application of instrument } & Appliances targeted \\
\hline $\begin{array}{c}\text { Legal instrument 1815 } \\
\text { and } 1970 \text {-Electricity } \\
\text { Efficiency Standards }\end{array}$ & $\begin{array}{l}\text { Minimum performance standards were applied to: } \\
\text { (1) customers unwilling to purchase efficient appliances } \\
\text { (2) get rid of inferior and used-appliances from the }\end{array}$ & $\begin{array}{c}\text { Refrigerators and air } \\
\text { conditioners }\end{array}$ \\
\hline
\end{tabular}

${ }^{3}$ Market failure is the absence of information about the electricity-drawing capabilities of appliances. 


\begin{tabular}{|c|l|c|}
\hline & $\begin{array}{l}\text { market } \\
\text { (3) Situations whereby the acquisition of information is } \\
\text { prohibitively expensive for individuals. }\end{array}$ & \\
\hline \multirow{2}{*}{$\begin{array}{l}\text { Labeling of appliances } \\
\text { (1) situations of inadequate knowledge or an information } \\
\text { barrier by introducing a performance standard } \\
\text { (2) huge variations in electricity performance between } \\
\text { similar units } \\
\text { (3) predicting the full benefits of the savings from } \\
\text { electricity efficiency. }\end{array}$} & $\begin{array}{c}\text { Refrigerators, air conditioners } \\
\text { and lamps }\end{array}$ \\
\hline $\begin{array}{c}\text { Installation of capacitor } \\
\text { banks }\end{array}$ & $\begin{array}{l}\text { To deal with electricity inductive loads, which are much } \\
\text { more common. }\end{array}$ & $\begin{array}{l}\text { Replacement of T-12 fluorescent } \\
\text { lamps with more energy efficient } \\
\text { T-5 fluorescent lamps }\end{array}$ \\
\hline $\begin{array}{c}\text { Information and } \\
\text { education }\end{array}$ & $\begin{array}{l}\text { Information and education were implemented due to: } \\
\text { (1) knowledge barriers in the acquisition and utilization of } \\
\text { efficient appliances; } \\
\text { (2) the need to address large target groups. }\end{array}$ & $\begin{array}{c}\text { Basic household appliances } \\
\text { such cookers, air conditioners, } \\
\text { televisions, fans, washing } \\
\text { machines, etc. }\end{array}$ \\
\hline $\begin{array}{c}\text { Refrigerator Rebate and } \\
\text { Exchange Scheme } \\
\text { (RRES) }\end{array}$ & $\begin{array}{l}\text { RRES was launched to accomplish the following: } \\
\text { (1) promote appliance efficiency; } \\
\text { (2) transform refrigerating efficiency market; } \\
\text { (3) Support consumers to purchase efficient refrigerators } \\
\text { when they turn in their old inefficient refrigerators in } \\
\text { working condition to the scheme. }\end{array}$ & $\begin{array}{r}\text { Commercial and household } \\
\text { refrigerators. }\end{array}$ \\
\hline
\end{tabular}

Lighting: about 78.5 percent of residential sector electricity consumption is attributed to the urban centres for lighting, freezing and cooling (Ghana Statistical Service [GSS], 2008). The Ministry of Energy, through the Energy Commission and Energy Foundation, phased-out the use of incandescent bulbs to be replaced by efficient electricity-based lighting appliances known as Compact Fluorescent Lamps (CFLs) in 2007 (Energy Foundation Ghana, 2007). CFLs contain a ballast meant to regulate the electricity current and are about four to five times more efficient compared to the traditional incandescent lamps (International Energy Agency [IEA], 2008). CFLs comprised various wattages ranging from 9W to 20W and consume a total of about $151.475 \mathrm{GWH}$ of electricity annually (Energy Commission, 2010). Table 4 illustrates a comparison of benefits derived from the utilization of incandescent lamps and CFLs. The information in Table 4 reveals that about 82 percent of electricity consumption per bulbs in a household was saved when CFLs are used rather than the incandescent lamps. This resulted in a significant reduction in household expenditure on electricity usage and save the country from expensive investment in generation plants.

Table 4: A comparison between incandescent and CFLs in Ghana.

\begin{tabular}{|c|c|c|}
\hline Comparison & Incandescent lamps & Compact fluorescent lamps \\
\hline Wattage & $60 w$ & $11 w$ \\
\hline Service life & 1,000 hours & 8,000 hours \\
\hline *Electricity consumption per year & $263 \mathrm{kWh}$ & $48 \mathrm{kWh}$ \\
\hline **Electricity cost per year & Ghc 31.56 or US $\$ 29.0352$ & Ghc 5.76 or US $\$ 5.2992$ \\
\hline
\end{tabular}

\section{Source: Energy Foundation Ghana (2008)}

In 2007, the EC and Energy Foundation implemented an array of innovative initiatives and activities to bring CFLs to the doorstep of the consumer. Table 5 indicates these activities and their descriptions.

Table 5: Initiatives towards the penetration of CFLs in Ghana

\begin{tabular}{|c|l|c|}
\hline Initiative & Description & Target group \\
\hline National compact & Free distribution of six million CFLs to most parts of the country, accounting & Ordinary and poor \\
\hline
\end{tabular}




\begin{tabular}{|c|l|c|}
\hline $\begin{array}{c}\text { fluorescent } \\
\text { exchange }\end{array}$ & and destruction of the retrieved incandescent lamps. & $\begin{array}{c}\text { people who could not } \\
\text { afford to pay high tariff. }\end{array}$ \\
\hline $\begin{array}{c}\text { Tertiary institution } \\
\text { project (TIP) }\end{array}$ & $\begin{array}{l}\text { In } 2006 \text { the Energy Foundation implemented TIP aimed at improving electricity } \\
\text { efficiency in the five public tertiary institutions. TIP comprised the installation of } \\
\text { capacitor banks and the replacement of T-12 fluorescent lights with more } \\
\text { electricity efficient T-5 fluorescent lamps. }\end{array}$ & $\begin{array}{c}\text { The five public } \\
\text { universities. }\end{array}$ \\
\hline $\begin{array}{c}\text { Save a watt } \\
\text { campaign }\end{array}$ & $\begin{array}{l}\text { This campaign educated the public on meter reading and how to identify fake } \\
\text { CFLs. Participants were awarded CFLs. }\end{array}$ & $\begin{array}{c}\text { People living in } \\
\text { compound houses, rural } \\
\text { dwellers and students. }\end{array}$ \\
\hline $\begin{array}{c}\text { Partnership with } \\
\text { traditional } \\
\text { authorities }\end{array}$ & $\begin{array}{l}\text { Staff of Energy Foundation made presentations on electricity conservation to } \\
\text { chiefs and solicited assistance to encourage their people to practice electricity } \\
\text { conservation. }\end{array}$ & Rural dwellers. \\
\hline Policy Fair & Organized series of seminars and exhibition on efficient appliances. & $\begin{array}{c}\text { Students and the } \\
\text { general public. }\end{array}$ \\
\hline
\end{tabular}

The mass adoption of CFC lamps as the standard lighting device resulted in a decrease of electricity consumption by 124 MW in 2008, transforming into an annual savings of over US\$33.6 million and reduced carbon emissions by 105000 ton per annum (Energy Review, 2011). Figure 3 presents information on monthly electricity peak load savings per customer population growth with respect to two scenarios: (1) the period before the electricity crisis, January 2005 to August 2006, and (2) the period after the crisis with the CFLs intervention, October 2007 to December 2009. The monthly peak load saving data is measures in megawatts while the customer population is measured in percentage. The ratio monthly peak load saving to customer population indicates the policy effect as it control for population growth before and after the implementation.

In the first scenario, there is an indication of a projection of the peak load to about $140 \mathrm{MW}$ per 1 percentage growth of customer base before the onset of the crisis. The peak loads would have been about 138 MW per 1 percentage growth of customer base before July 2008. The second scenario indicated peak loads witnessed after the crisis and with the CFLs policy intervention. This scenario recorded peak loads of about $108 \mathrm{MW}$ per 1 percentage growth of customer base by November 2009. A comparison of the two scenarios indicates a peak load reduction of about $30 \mathrm{MW}$. There is a huge probability that this saving is attributed to the CFLs policy intervention since it was the principal electricity policy initiative undertaken during the crisis.

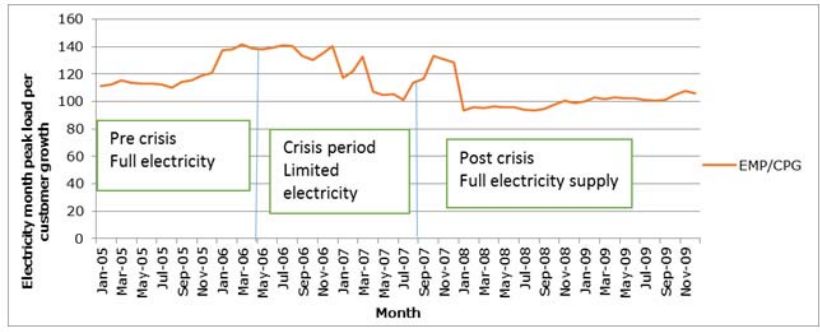

Figure 3: Average monthly electricity peak load per customer growth

\subsection{Industrial sector electricity efficiency policies}

In Ghana, the industrial sector on average accounts for about 54 percent of the total electricity used from 2000 to 2010 (Energy Commission, 2010). Electricity waste in this sector is also attributed to the application of inefficient appliances to draw electricity (Energy Foundation, 2005). This implies there are significant prospects for saving electricity and costs of production. Based on this, electricity efficiency in the industrial sector can be increased through three different methods as follows: (1) electricity saving by management; (2) electricity saving by technologies, and (3) electricity saving by regulations and standards. The study succinctly discusses them as follows:

Electricity management: it entails setting up a strategy to meet electricity demand as and when required. Generally, it is accomplished through the adjustment and optimization of electricity supply systems and processes as a way to reduce electricity needs per unit of output, at the same time keeping constant or reducing total costs of producing 
the output from these systems (Abdelaziz et al., 2011). Its objective is to minimize electricity expenditure without compromising production and quality as well as reducing environmental effects. In Ghana, most industries adopt electricity management (EM) strategies that are meant to tackle ineffective plants and manage them to exploit costeffective electricity saving opportunities. The following are some of the initiatives adopted by industries in undertaking electricity management effectively: (1) upgrading boiler efficiency; (2) continuous monitoring of electricity consumption and making a comparison with production levels; (3) educating employees to turn off lights and equipment when they are idle; and (4) engineering evaluation and feasibility studies to enhance the practicability of investment proposals.

Tema Lube Oil Company Ltd, a beneficiary of the Energy Foundation's pilot Monitoring and Targeting Electricity Management Scheme significantly improved its electricity efficiency, as it experienced about a 35 percent reduction in electricity bills representing an annual cost saving of about 40 million Ghana cedis or US \$19.3 million (Energy Foundation, 1999a).

Electricity saving technologies: these entail the application of efficient appliances to reduce industrial use of electricity. The main objective of efficient appliance technology is to reduce maximum demand. The Energy Foundation (1999a) identified efficiency appliances and installations used in the industrial sector as follows: (1) installation of variable speed drivers; (2) power factor correction; and (3) installation of skylights.

Ghana Textile Printing (GTP) Limited, a textile manufacturing company, applied electricity saving technologies to save electricity by about 6.5 percent, representing about 35.19 million cedis or US $\$ 17$ million in monetary terms. Before the installation of these appliances GTP, on average, consumed about $294.71 \mathrm{kWh}$ of electricity per 1000 yards of textile produced per month. However, after the installation, the monthly average electricity consumed reduced to $275.55 \mathrm{kWh}$.

Again, the Ghana Cylinder Manufacturing Company Limited (GCMC) prior to the installation of efficient appliances experienced maximum demand of about 240kVA and operating at a power factor of 0.68 (Energy Foundation, 1999b). Industries whose plant power factor falls below the minimum industry standard requirement of 0.9 attract a surcharge given by the formula: $P F S=\left(P F_{\min }-P F_{\text {actual }}\right) / P F_{\min } \times M D \times M D_{\text {charge }}$, where $P F_{\text {actual }}$ denotes the actual average power factor of the plant measured by the meter in any billing cycle, $M D$ denotes the maximum demand of the billing cycle, kVA; $M D_{\text {charge }}$ denotes the prevailing charge per unit of maximum demand.

To reduce the maximum demand, GCMC installed a 200-kVAR capacitor bank at the factory, which improved the power factor from 0.68 to 0.82 and subsequently reduced electricity demand from 240kVA to 160kVA. Table 6 shows an average monthly electricity saving of 38.17 million cedis or US $\$ 18.4$ million due to the reduction in the maximum demand and the avoidance of power factor surcharges. This represents about 33 percent of electricity saved.

Table 6: Electricity saving due to efficient technologies

\begin{tabular}{|l|l|}
\hline Variable & Amount in Ghana cedis (million) and US\$ \\
\hline Total investment cost & Ghc 16.758 or US \$8.1million \\
\hline $\begin{array}{l}\text { Annual electricity saved }=12^{\star} \text { Average monthly savings } \\
{ }^{*} \text { Cedi-dollar exchange rate } 1999=0.4836\end{array}$ & $\left(12^{\star} 3,181,054\right)=$ Ghc 38.17 or US $\$ 18.4$ million \\
\hline
\end{tabular}

Source: Energy Foundation (1999b)

The installation of efficient appliances has been effective in reducing the cost of electricity at the two companies (GTP and GCMC). This has the potential of freeing financial resources to undertake productive ventures, which will ultimately provide the companies with a competitive edge in their product markets.

Regulations or standards: they are mandatory policies for enhancing electricity efficiency in industries (Abdelaziz et al., 2011). In Ghana, regulations or standards include the adoption of electricity audits, electricity management, minimum electricity performance standards (MEPS) for air conditioners and industrial motors, electricity courses and demarcation of companies into smaller electricity account centres (ECA) (Energy Foundation, 1999c).

\section{Factors that Hinder the Utilization and Extensive Deployment of the Technologies}

There are a number of factors that militate against the effective implementation of electricity efficiency policies. Brown (2001) categorized these barriers into market failures and market barriers. The market failures emanate from imperfections in the functioning of the market while market barriers stem from impediments in the diffusion of efficiency policies. Table 7 summarizes the barriers to implementing efficiency policies. 
Table 7: Barriers to electricity efficiency (EE) policies in Ghana

\begin{tabular}{|c|c|c|}
\hline $\begin{array}{c}\text { Categories of } \\
\text { barriers }\end{array}$ & Possible causes & Possible solution(s) \\
\hline $\begin{array}{c}\text { Policy/ } \\
\text { Regulatory }\end{array}$ & $\begin{array}{l}\text { (1) Political influence on electricity pricing. } \\
\text { (2) Import duties on efficiency appliances. } \\
\text { (3) Underdeveloped institutional framework for EE. } \\
\text { (4) Lack of appliance standards for other appliances } \\
\text { and building EE codes, lack of testing, poor } \\
\text { enforcement. }\end{array}$ & $\begin{array}{l}\text { (1) Set up independent regulatory bodies. } \\
\text { (2) Resource institutions in the electricity sector. } \\
\text { (3) Government should establish legal and institutional } \\
\text { infrastructure for ensuring compliance with EE } \\
\text { requirements. } \\
\text { (4) Government should put in place institutional } \\
\text { frameworks to ensure regular cooperation and } \\
\text { exchanges on energy EE issues between the public } \\
\text { sector and financial institutions. }\end{array}$ \\
\hline $\begin{array}{c}\text { Appliance/ } \\
\text { Service } \\
\text { Providers }\end{array}$ & $\begin{array}{l}\text { (1) High project development costs. } \\
\text { (2) Limited demand for EE goods. } \\
\text { (3) Diffuse/diverse markets. } \\
\text { (4) New contractual mechanisms such as energy } \\
\text { service companies (ESCOs) } \\
\text { (5) Limited technical, business, risk management } \\
\text { skills } \\
\text { (6) Limited financing/ equity }\end{array}$ & $\begin{array}{l}\text { (1) Reduce interest rate and transaction cost } \\
\text { (2) Encourage capital lease } \\
\text { (3) Attract third-party capital } \\
\text { (4) Review MEPS threshold levels periodically to keep } \\
\text { pace with technological advances. }\end{array}$ \\
\hline End-user & $\begin{array}{l}\text { (1) Lack of awareness of EE } \\
\text { (2) Higher project development and upfront costs } \\
\text { (3) Ability/willingness to pay incremental cost } \\
\text { (4) Low EE benefits relative to other costs } \\
\text { (5) Perceived risks of new technology systems. } \\
\text { (6) Mixed incentives } \\
\text { (7) Behavioural biases } \\
\text { (8) Lack of credible data }\end{array}$ & $\begin{array}{l}\text { (1) Create and increase awareness concerning } \\
\text { electricity efficiency } \\
\text { (2) Subsidize EE appliances } \\
\text { (3) Provision of mobile electricity management service } \\
\text { for SME's. } \\
\text { (4) Government should promote risk mitigation } \\
\text { instruments, such as securitization or public-private } \\
\text { partnerships }\end{array}$ \\
\hline
\end{tabular}

\section{The Role of Institutions in Promoting Electricity Efficiency}

Ghana's electricity institutions can be put into four categories namely: (i) Policy making institutions such as the Ministry of Energy (MoE); (ii) regulatory institutions, which include the Energy Commission (EC), Public Utility Regulatory Commission (PURC) and Energy Foundation (EF); (iii) generation, transmission and distribution institutions, which include Volta River Authority (VRA), Sunon Asogli Power Plant [SAPP], Ghana Grid Company Limited (GRIDCo), Northern Electricity Department Company (NEDCo) and the Electricity Company of Ghana (ECG); and (4) arbitration institutions such as electricity courts.

The introduction of legal instruments (1815 and 1970) Electricity Efficiency Standards, labelling and free distribution of CFLs in 2005 and 2007, are elements of institutional interventions to accomplish efficient usage of electricity. This is because consumers and producers usually experience some difficulty in changing from one technology to another due to the associated transaction costs. These interventions should only be allowed to stay in the market as long as the market cannot effectively displace the existing inefficient technology (incandescent lamps in Ghana's case), but are quickly withdrawn once market forces begin to show signs of functioning properly. This creates a situation known as market transformation. In this regard, a market transformation is a change in the structure of a market or the behaviour of participants in a market, which produces an increase in the adoption of electricity-efficient products, services, or practices (Rosenberg \& Hoefgen, 2009). In other words, a market transformation means that the volumes of purchases of specific inefficient products are transformed into the purchasing of more efficient appliances (Schlegal et al., 1997). Therefore, market transformation assists in reducing electricity consumption and stimulates a higher electricity efficiency in the economy.

A key justification for institutional intervention to transform the appliances market has been due to market failures of an unregulated market (Hausman \& Joskow, 1982). The inefficient nature of the market encourages the commercialization and use of inefficient appliances that are characterized by very high electricity intensity. Market failure of electricity efficiency programmes is primary attributed to the following theoretical sources: (1) electricity price is very low and thus distorts purchasing decisions for appliances that are inefficient; (2) the tendency of consumers to underestimate total lifecycle costs of the appliances with varying efficiencies; and (3) the tendency of consumers to 
discount rates for assessing appliance lifecycle costs that may be very high and thus stimulate their acquisition of more electricity intensity appliances (Hausman \& Joskow, 1982). Figure 4 shows how institutions transform the appliance market.

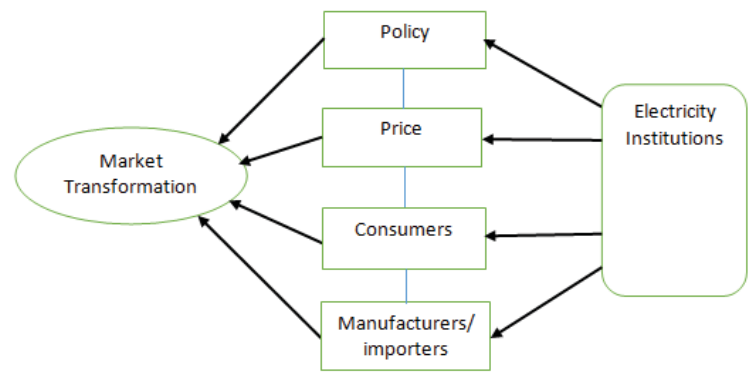

Figure 4: Institutional transformation of appliance market

Institutions can transform the market by policy measures affecting information, education and regulation (Boardman, 2004). The policy measures can be categorized into two: (1) product policy, which affect the appliances directly; and (2) economic policy, which affects the operation costs of the appliances (Boardman, 2004). In Ghana some direct product policy measures have been the introduction of the MEPS for air conditioners and refrigerators, labelling and the national CFLs exchange in 2007. On the other hand, the economic policy comprises the provision of subsidies to importers of appliances that meet the minimum standards, labelling requirements and the Refrigerator Rebate and Exchange Scheme (Ministry of Energy, 2012).

Despite the passage of the regulations and labels banning the commercialization of second-hand refrigerators, air-conditioners and incandescent lamps by parliamentary assent through the legislative instrument (LI 1932), many Ghanaian importers illegally bring these appliances into the country (Ghana News Agency, 2012). This is confirmed by a recent United Nations report which indicated that 85 percent of all electrical and electronic appliances imported are second-hand (United Nations, 2012). This is a vivid indication that the institutions and regulatory bodies mandated to enforce the ban are weak in the discharge of their duties, and the education of Ghanaians on the benefits of purchasing and installing the new and efficient appliances needs to be strengthened and pursue vigorously.

Institutions can also use prices of either electricity or appliances to influence market transformation in two broad ways: (1) they reduce wasteful conduct when it exists; and (2) they encourage the acquisition of efficient appliances through rational economic decision making (Boardman, 2004). When the electricity price is raised to their long-run marginal cost consumers are compelled to reduce waste through the utilization of appliances in the short run. On the other hand, when efficient appliances prices are high and consumers are unable to compare the marginal costs of these efficient appliances characterized by lower operation costs through a life-cycle evaluation, they will acquire inefficient ones (Boardman, 2004). This will negatively affect market transformation. The EF and EC have attempted to address this issue by education, seminars and electricity festivals.

The activity of manufacturers or importers symbolizes the supply side of electricity efficiency programmes and is a primary determinant of market transformation (Boardman, 2004). Any minimum standard and labelling programme will only be successful, the greater the willingness of manufacturers or importers to certify their products and the greater the willingness of sellers to market such products. Apart from policy, the only reason why manufacturers will undertake electricity efficiency programme is when it is in their interest and to their benefit (Banerjee \& Solomon, 2003). Therefore to improve electricity efficiency the manufacturers should commercialize more efficient appliances and make them identifiable to the consumers. The MoE and the EC have addressed this problem through the Refrigerator Exchange Programme and Rebate, which commenced in 2012.

Finally, institutions can use consumer response to influence the success of an electricity efficiency policy since it represents an indicator for the assessment of public acceptance of the policy (Banerjee \& Solomon, 2003). Consumer response has three elements: awareness, understanding and conduct (Banerjee \& Solomon, 2003). Awareness relates to what extent the consumers possess information about the presence of the appliances; understanding is the consumers' ability to effectively make sense of the relationship between environmental issues, the meaning of the label and the required measures to produce results; conduct relates to the extent to which consumers' awareness and understanding have transformed buying the appliances (Banerjee \& Solomon, 2003). Quantitatively, awareness and 
understanding can be measured through consumer survey studies such as the "Final Report-CFL Exchange Programme Impact Assessment" undertaken by the EC in 2009.

\section{Conclusions}

Electricity end-use efficiency is relevant from the perspective of reducing the growth in electricity demand and global carbon emission without reducing the quality of usage. The technologies and policies to appreciably increase electricity end-use efficiency abound for practically all residential and industrial end-users. Despite their noticeable merits, many of these technologies and policies are accepted at a slow pace in the market, attributed to various market failures. The role of institutions to surmount these failures and improve electricity end-use efficiency have been relatively effective in conserving electricity.

\section{References}

Abdelaziz, E.A., Saidur, R., \& Mekhilef, S. (2011). A review of energy saving strategies in industrial sectors. Renewable and Sustainable Energy Reviews, 15, 150-168.

Adom, P.K, Bekoe, W. \& Akoena, K.K. (2012). Modelling aggregate domestic electricity demand in Ghana: An autoregressive distributed lag bounds cointegration approach. Energy Policy, 42, 530-537.

Agyarko, K. (2010). Energy efficiency drive: The story of Ghana, Accra, Ghana: Energy Commission of Ghana.

Anderson, V. (1993). Energy efficiency policies. New York \& London: Routledge.

Banerjee, A. \& Solomon, B.D. (2003). Eco-labeling for energy efficiency and sustainability: a meta-evaluation of US programs. Energy Policy, 31,109-123.

Boardman, B. (2004). New directions for household energy efficiency: Evidence from the UK. Energy Policy, 32, 1921-1933.

Brown, M.A. (2001). Market failures and barriers as a basis for clean energy policies. Energy Policy, 29(14), 1197-1207

Carley, S. (2012). Energy demand-side management: New perspectives for a new era. Journal of Policy Analysis and Management. 31(1), 6-32

Constantine, S., Andrea, D., Sajid, H., McMahon, J.E., \& Rosenquist, G. (1999). Ghana Residential energy use and appliance ownership survey: Final report on the potential impact of appliance performance standards in Ghana. Berkeley,C.A.: Lawrence Berkeley National Laboratory.

De Melo, C.A., \& Jannuzzi, G.D.M. (2010). Energy efficiency standards for refrigerators in Brazil: A methodology for impact evaluation. Energy Policy, 38, 6545-6550.

Dubin, J.A., \& McFadden, D.L. (1984). An econometric analysis of residential electric appliance holdings and consumption. Econometrica, 52(2), 345-362.

Dowuona-Hammond, C., \& Atuguba, R. (2006). The policy and legal framework for consumer protection in Ghana: Final report. Ghana: Friedrich Ebert Foundation (FES).

Energy Commission. (2006). Strategic national energy plan 2006 - 2020, Accra, Ghana: Energy Commission.

Energy Commission. (2010). National energy statistics. Accra, Ghana: Energy Commission.

Energy Commission. (2012). National energy statistics. Accra, Ghana: Energy Commission.

Energy Commission. (2013). National energy statistics. Accra, Ghana: Energy Commission.

Edjekumhene, I. (2007). Tariffs and the poor. In A. Brew-Hammond, \& F. Kemausuor (Eds.), Energy crisis in Ghana: Drought, technology or policy? Kumasi, Ghana: Kwame Nkrumah University of Science and Technology (KNUST), College of Engineering.

Energy Foundation (2000). Towards energy efficient economy: annual report and financial statements. Energy Foundation.

Energy Foundation. (2005). Towards energy efficient economy: Annual report and financial statements. Ghana: Energy Foundation.

Energy Foundation. (1999a). Saving energy in industry: Monitoring and targeting energy management: The case of Tema Oil Company Limited. Ghana: Energy Foundation.

Energy Foundation. (1999b). Saving energy in industry: Energy management in a metal fabrication factory, Ghana Cylinder Manufacturing Company Limited (GCMC). Good practice case study 003. Ghana: Energy Foundation.

Energy Foundation (1999c). Saving energy in industry: integrated energy management. The Ghana Textile Printing Company Ltd. Energy Foundation

Energy Review. (2011). Measurement and evaluation of refrigerator energy consumption and efficiency in Ghana. Ghana: Energy Commission.

Ghana Grid Company Limited (GRIDCo). (2010). Ghana Wholesale Power Reliability Assessment 2010. Ghana: Power System Energy Consulting (PSEC).

Ghana News Agency. (2012). Sekondi-Takoradi inundated with banned electrical appliances. <www.modernghana.com/news /390490/1/sekondi-takoradi-inundated-with-banned-electrical-.html>. Accessed: date required

Ghana Statistical Service. (2008). Ghana Living Standards Survey, 5th ed.). Accra, Ghana: Republic of Ghana.

Gillingham, K., Newell,R.G. \& Palmer, K. (2009). Energy efficiency economics and policy. , Discussion Paper, DP 09-13. Washington, 


\section{D.C.: Resources for Future}

Jaffe, A. B., Newell, R. \& Stavins, R.N. (1999). Energy-efficient technologies and climate change policies: Issues and evidence. Washington, DC: Resources for the Future.

Hausman, J.A. \& Paul L. Joskow, P.L. (1982). Evaluating the costs and benefits of appliance efficiency standards. American Economic Review, 72(2),, 220-225.

International Energy Agency [IEA]. (2008). Worldwide Trends in Energy Use and Efficiency Key Insights from IEA Indicator Analysis, OECD/International Energy Agency.

Leonard, J.M. \& Decker, C.S. (2012). Determinants of voluntary electricity demand management program participation. Utility Policy, 20(1), 17-21.

Levine, M.D., Koomey, J.G., Price, L, Geller, H. \& Nadeli, S. (1995). Electricity end-use efficiency: Experience with technologies, markets, and policies throughout the world. Energy, 20(1), 37-61.

Ministry of Energy. (2010). National energy policy. Accra, Ghana: Republic of Ghana.

Ministry of Finance. (2012). Budget statements. Accra, Ghana: Republic of Ghana.

Ofosu-Ahenkorah, A.K. (2002). Promoting end-use electrical energy efficiency in Ghana. Accra, Ghana: Ghana Energy Foundation.

Schlegal, J., Goldberg, M., Raab, J., Prahl, R., Kneipp, M. \& Violette, D. (1997), Evaluating energy efficiency programs in a restructured industry environment: A handbook for PUC staff. Washington D.C.: National Association of Regulatory Utility Commissioners.

Rosenberg, M.\& Hoefgen, L. (2009). Market Effects and Market Transformation: Their Role in Energy Efficiency Program Design and Evaluation. CIEE Market Effects Program. Oakland: California Institute for Energy and Environment.

Weil, S. \&McMahon, J. (2005). Energy efficiency labels and standards: A guidebook for appliances, equipment and lighting. (2nd ed.). Washington, D.C.: Collaborative Labeling and Appliance Standards Program (CLASP).

World Bank. (2012). Africa development indicators 2012. Washington, D.C.: World Bank.

United Nations. (2012). Domestic consumption is main contributor to Africa's e-waste. United Nations Environment Programme.

Volta River Authority. (2012). Annual report. Accra, Ghana: Government of Ghana. 
